\title{
1 In vitro evaluation of the activity of terpenes and cannabidiol against
}

\section{Human Coronavirus E229}

4 Authors - Lior Chatow, Adi Nudel, Iris Nesher, David Hayo Hemo, Perri Rozenberg,

5 Hanna Voropaev, Ilan Winkler, Ronnie Levy, Zohar Kerem, Zohara Yaniv, Nadav Eyal

7 Eybna Technologies Ltd., Givat Hen, Israel 43905

8

$9 \quad$ \#Corresponding author: Lior Chatow

10 Eybna Technologies Ltd.

11 Pa'amei Aviv 23

12 Givat Hen, 43905 Israel

$13 \quad$ Tel.: +18887244813

14 Email: info@eybna.com

15

16 Running title: Activity of terpenes and cannabidiol against coronavirus

17 


\section{Abstract}

20 The activity of a new, terpene-based formulation, code-named NT-VRL-1, against Human

21 Coronavirus (HCoV) strain 229E was evaluated in human lung fibroblasts (MRC-5 cells),

22 with and without the addition of cannabidiol (CBD). The tested formulation exhibited an

23 antiviral effect when it was pre-incubated with the host cells prior to virus infection. The

24 combination of NT-VRL-1 with CBD potentiated the antiviral effect better than the

25 positive controls pyrazofurin and glycyrrhizin. There was a strong correlation between

26 the quantitative results from a cell-viability assay and the cytopathic effect seen under

27 the microscope after $72 \mathrm{~h}$. To the best of our knowledge, this is the first report of activity

28 of a combination of terpenes and CBD against a coronavirus.

30 Keywords: Antiviral; HCoV-229E; Terpenes; CBD; Cannabis; COVID-19 


\section{Introduction}

Coronaviruses are enveloped, non-segmented, positive-strand RNA viruses of the family Coronaviridae that cause a wide spectrum of illnesses in humans, including respiratory and gastrointestinal diseases (1). To date, seven human coronaviruses (HCoVs) have been identified. Four of those, HCoV-229E, HCoV-OC43, HCoV-NL63 and HCoV-HKU1, are non-zoonotic and cause worldwide outbreaks of upper respiratory tract infections predominantly in the winter (2). The severe acute respiratory syndrome coronavirus 2 (SARS-CoV-2) has produced an epidemic of Coronavirus Disease 2019 (COVID-19) that started on 31 December 2019 in China and then spread to different regions and countries. According to the WHO (3), as of January 26th, 2021, there have been a total of 98,925,221 confirmed cases of COVID19 worldwide, including 2,127,294 deaths.

This outbreak has led to a search for active antiviral compounds to treat this disease. While SARS-CoV-2 is highly contagious and can only be studied in a biosafety level 4 facility, working with the less virulent strain HCoV-229E is considered a good alternative for preliminary research $(2,4,5)$. HCoV-229E is associated with various respiratory illnesses ranging from the common cold to severe pneumonia (6).

Recently, the potential of phytochemicals, such as terpenes, for use as potent antiviral agents has received considerable attention, especially because these substances are naturally abundant with relatively low toxicity and cost (7). Terpenes are natural, volatile compounds primarily extracted from plants, which contain only carbon, hydrogen and oxygen atoms. In plants, terpenes act as chemoattractants or chemorepellents (8) and are largely responsible for plant fragrances. In animals and humans, terpenes exhibit a variety of pharmacological 
properties, including anti-inflammatory (9), analgesic (10), antimicrobial (11) and antiviral (12) properties. A wide range of in vitro studies have demonstrated terpenes' potential for use against a wide range of viruses such as herpes simplex virus (13), bronchitis virus (14), West Nile virus (15) and HIV-1 (16).

As isolated compounds and in plant essential oils, terpenes have been shown to have antiviral effects against several types of HCoVs. Glycyrrhizin, a triterpene found in licorice roots, was one of the first compounds found to be active against SARS coronavirus (SARS-CoV) in vitro; it was shown to inhibit SARS-CoV replication with an $\mathrm{EC}_{50}$ of $365 \mu \mathrm{M}$ (17). Glycyrrhizin has also been used to successfully treat SARS patients (18). Laurus nobilis essential oil, with beta-ocimene, 1,8-cineole, alphapinene and beta-pinene as its main constituents, was found to exert antiviral activity against SARS-CoV with an $\mathrm{IC}_{50}$ value of $120 \mathrm{mg} / \mathrm{mL}$ (19).

Even though the vaccination of the world's population against COVID-19 has begun and is expected to proceed gradually, with no clear expectation of completion. Some individuals will not be vaccinated due to personal choice or health limitations. In addition, several population groups such as younger age groups will be the last to get vaccinated. A natural antiviral solution with minimal side effects that can be used alone or in conjunction with vaccines as a preventative treatment may be a safe and relatively easy way to reduce infection in those populations.

The goal of the present study was to evaluate the antiviral activity of a proprietary terpene formulation (code named NT-VRL-1) against HCoV-229E, with and without the addition of cannabidiol (CBD), and the mode of antiviral action of this formulation during the viral multiplication cycle. The NT-VRL-1 formulation consisted of 30 natural terpenes that are found in cannabis, as well as other plants. 
81 The therapeutic activity of these compounds was evaluated in terms of the

82 cytopathic effect observed under an inverted microscope and an in vitro cell viability

83 XTT assay involving human lung fibroblasts (MRC-5 cells) in which the mitochondrial

84 activity of those cells was examined.

85

\section{Materials and Methods}

\section{Materials and reagents}

MRC-5 cells and the HCoV-229E strain were purchased from the American

Type Culture Collection (ATCC; Manassas, Virginia, United States). All media

ingredients and the XTT-based viability assay kit were purchased from Biological

Industries (Beit HaEmek, Israel). CBD was purchased from Recipharm Israel (Ness

Ziona, Israel). NT-VRL-1 was obtained from Eybna Technologies (Givat Hen, Israel).

Glycyrrhizin was obtained from Penta International Corporation (New Jersey, USA)

and pyrazofurin was purchased from Sigma (Jerusalem, Israel).

\section{Cytotoxicity of compounds}

MRC- 5 cells were plated at $1 \times 104$ cells/well in 96-well plates in minimum essential medium Eagle (EMEM) supplemented with $10 \%$ fetal calf serum and then incubated at $37^{\circ} \mathrm{C}$ with $5 \% \mathrm{CO} 2$. The next day, the medium was discarded and $100 \mu \mathrm{L}$ of EMEM supplemented with $1 \%$ fetal calf serum was added to the cells, together with the compounds. The following concentrations were tested for each potential treatment. CBD: $2 \mu \mathrm{g} / \mathrm{mL}, 5 \mu \mathrm{g} / \mathrm{mL}$ and $10 \mu \mathrm{g} / \mathrm{mL}$. NT-VRL-1: $5 \mu \mathrm{g} / \mathrm{mL}, 10 \mu \mathrm{g} / \mathrm{mL}, 50$ $\mu \mathrm{g} / \mathrm{mL}$ and $100 \mu \mathrm{g} / \mathrm{mL}$. NT-VRL-1 + CBD: $10 \mu \mathrm{g} / \mathrm{mL}+1 \mu \mathrm{g} / \mathrm{mL}$ and $10 \mu \mathrm{g} / \mathrm{mL}+3$ 
$\mu \mathrm{g} / \mathrm{mL}, 500 \mu \mathrm{g} / \mathrm{mL}$ and $1000 \mu \mathrm{g} / \mathrm{mL}$. The cells were incubated for an additional $72 \pm 2$

$\mathrm{h}$ at $34^{\circ} \mathrm{C}$ and $5 \% \mathrm{CO}$. Finally, the cells were subjected to an XTT assay. Based on the

results of this work, we determined the non-toxic concentrations of the compounds

108 to be used in the efficacy evaluations: CBD $(0.5 \mu \mathrm{g} / \mathrm{mL}$ and $1 \mu \mathrm{g} / \mathrm{mL}), \mathrm{NT}-\mathrm{VRL}-1(2$

$109 \mu \mathrm{g} / \mathrm{mL}, 5 \mu \mathrm{g} / \mathrm{mL}$ and $10 \mu \mathrm{g} / \mathrm{mL}), \mathrm{NT}-\mathrm{VRL}-1+\mathrm{CBD}(10 \mu \mathrm{g} / \mathrm{mL}+1 \mu \mathrm{g} / \mathrm{mL})$, pyrazofurin

$110(5 \mu \mathrm{g} / \mathrm{mL})$ and glycerrihizin $(400 \mu \mathrm{g} / \mathrm{mL})$.

\section{Efficacy of compounds - Cell pretreatment}

114 supplemented with $10 \%$ fetal calf serum, and then incubated at $37^{\circ} \mathrm{C}$ and $5 \% \mathrm{CO}_{2}$.

115 The next day, the medium was discarded and $100 \mu \mathrm{L}$ of EMEM supplemented with

$1161 \%$ fetal calf serum was added to the cells, supplemented with the compounds at

117 concentrations previously identified as nontoxic. The cells were incubated for $1 \mathrm{~h}$ at

$11834^{\circ} \mathrm{C}$ and $5 \% \mathrm{CO}_{2}$. Next, $1 \mu \mathrm{L}$ of medium or virus at 100 times the concentration of

119 the infective dose (1:340 dilution) was added to the cells. The cells were incubated

120 for an additional $72 \pm 2 \mathrm{~h}$ at $34^{\circ} \mathrm{C}$ and $5 \% \mathrm{CO}_{2}$. Under an inverted microscope, a

121 photograph was taken of the cells in each treatment at 24,48 and $72 \mathrm{~h}$ post-

122 infection. A virus-induced cytopathic effect was observed in comparison with the

123 parallel virus control and cell control. Finally, cells were subjected to an XTT assay.

125 Efficacy of compounds - Virus pretreatment

127 supplemented with $10 \%$ fetal calf serum, and then incubated at $37^{\circ} \mathrm{C}$ and $5 \% \mathrm{CO}_{2}$.

128 The next day, $120 \mu \mathrm{L}$ of EMEM supplemented with $1 \%$ fetal calf serum was added to 
129 the wells, supplemented with the compounds at concentrations previously identified

130 as nontoxic. The virus was mixed with the compounds in a U-shaped plate and then

131 incubated for $1 \mathrm{~h}$ at $34^{\circ} \mathrm{C}$ and $5 \% \mathrm{CO}$. Then, $1.2 \mu \mathrm{L}$ medium or virus at 100 times the

132 concentration of the infective dose was added to the wells. Next, $100 \mu \mathrm{L}$ of the virus

133 + compounds mixture was added to the cells after medium was removed and the

134 cells were incubated at $34^{\circ} \mathrm{C}$ and $5 \% \mathrm{CO}_{2}$ for an additional $72 \pm 2 \mathrm{~h}$. Under an

135 inverted microscope, photographs of the cells in each treatment were taken at 24,

13648 and $72 \mathrm{~h}$ post-infection. The virus-induced cytopathic effect was observed in

137 comparison with the parallel virus control and cell control. Finally, cells were

138 subjected to an XTT assay.

Efficacy of compounds - Post-adsorption

MRC- 5 cells were plated at $1 \times 10^{4}$ cells/well in 96-well plates in EMEM

142 supplemented with $10 \%$ fetal calf serum, and then incubated at $37^{\circ} \mathrm{C}$ and $5 \% \mathrm{CO}_{2}$.

143 The next day, medium was discarded and EMEM supplemented with $1 \%$ fetal calf

144 serum was added to the cells with or without $1 \mu \mathrm{L}$ of virus at 100 times the

145 concentration of the infective dose. The cells were then incubated for $1 \mathrm{~h}$ at $34^{\circ} \mathrm{C}$

146 and $5 \% \mathrm{CO}_{2}$. Then, medium was discarded and $100 \mu \mathrm{L}$ of EMEM supplemented with

$1471 \%$ fetal calf serum was added to the cells, supplemented with the compounds at the

148 concentrations previously identified as nontoxic and $1 \mu \mathrm{L}$ of media or virus at 100

149 times the concentration of the infective dose. The cells were incubated for an

150 additional $72 \pm 2 \mathrm{~h}$ at $34^{\circ} \mathrm{C}$ and $5 \% \mathrm{CO}_{2}$. Under an inverted microscope, photographs

151 were taken of the cells in each treatment at 24,48 and $72 \mathrm{~h}$ post-infection. The 
152 virus-induced cytopathic effect was observed in comparison with the parallel virus

153 control and cell control. Finally, cells were subjected to an XTT assay.

XTT-based viability assay

At the end of each incubation period, media was discarded from all wells and

$157100 \mu \mathrm{L}$ of fresh culture medium was added to the cells together with $50 \mu \mathrm{L}$ of XTT

158 reagent. OD was measured at $450 \mathrm{~nm}$ (after subtraction of the non-specific OD at

$159620 \mathrm{~nm})$.

160

161 Results

162

163

164

165

166

167

168

170

171

172

173

174

175

\section{Cytotoxicity of compounds}

The non-cytotoxic concentrations of the various compounds were

determined as the concentrations that did not lead to excess cell death, as compared

to untreated cells. As shown in Figure 1, the non-toxic concentrations were: $\mathrm{CBD} \leq 1$ $\mu \mathrm{g} / \mathrm{mL}, \mathrm{NT}-\mathrm{VRL}-1 \leq 10 \mu \mathrm{g} / \mathrm{mL}$, pyrazofurin $\leq 10 \mu \mathrm{g} / \mathrm{mL}$ and glycyrrhizin $\leq 500 \mu \mathrm{g} / \mathrm{mL}$.

\section{Efficacy of compounds - Cell pretreatment}

MRC-5 cells were pretreated with the compounds prior to inoculation with

HCoV-229E. As shown in Figure 2, the viability of cells that were infected with HCoV-

$229 \mathrm{E}$, but otherwise untreated, was reduced to $\sim 40 \%$ of the viability of the

uninfected control cells. Pre-incubation of the cells with all of the compounds prior

to virus inoculation rescued the cells and increased the level of cell viability. The

combination of $10 \mu \mathrm{g} / \mathrm{mL} \mathrm{NT-VRL-1} \mathrm{with} 1 \mu \mathrm{g} / \mathrm{mL}$ CBD was the most effective

treatment associated with the highest level of cell viability $(p<0.001)$. This pattern 
176 was also observed in terms of the cytopathic effect seen under the microscope after

$17772 \mathrm{~h}$. Swelling and clumping of the MRC- 5 cells was observed $72 \mathrm{~h}$ after viral

178 infection (Figure 3). Cell pretreatment with NT-VRL-1 alone (Figure 3C) or NT-VRL-1 +

179 CBD (Figure 3D) before viral infection prevented a cytopathic effect.

180

181 Efficacy of compounds - Virus pretreatment

182 HCoV-229E was incubated with the compounds before it was introduced to the

183 MRC-5 cells. As shown in Figure 4, inoculation with HCoV-229E (pre-incubation with

184 assay medium) reduced the viability to $80 \%$. Pre-incubation of the virus with 10

$185 \mu \mathrm{g} / \mathrm{mL}$ NT-VRL-1 $+1 \mu \mathrm{g} / \mathrm{mL}$ CBD prior to its introduction to host cells elevated cell

186 viability back to the level observed for the control $(p<0.001)$. In addition, virus

187 pretreatment with NT-VRL-1 + CBD prevented a cytopathic effect after the cells were

188 inoculated with the virus (Figure 5)

189

Efficacy of compounds - Post-adsorption

When the compounds were added to the cells after virus adsorption, the

192 viability of the HCoV-229E-infected cells was reduced to only $~ 70 \%$ of the control, as

193 shown in Figure 6. Under these conditions, $10 \mu \mathrm{g} / \mathrm{mL}$ NT-VRL-1 $+1 \mu \mathrm{g} / \mathrm{mL}$ CBD

194 prevented cell death and preserved a level of cell viability similar to that observed

195 for the control $(\mathrm{p}<0.001)$. Pyrazofurin at $5 \mu \mathrm{g} / \mathrm{mL}$ also enhanced cell viability $(\mathrm{p}<$

196 0.05) relative to the untreated, infected control. Similar results were observed in

197 terms of the cytopathic effect after $72 \mathrm{~h}$, at which point NT-VRL-1 by itself (Figure

198 7C) and NT-VRL-1 + CBD (Figure 7D) both prevented cell damage. 


\section{Discussion}

Human coronaviruses have presented a great burden to global health since

202 the 1960's (20). The development of novel, effective antiviral solutions with low

203 toxicity and few side effects is a matter of great interest. Secondary plant

204 metabolites such as terpenes and cannabinoids have been shown to have significant

205 antiviral potential and low toxicity, making them good candidates for use as antiviral

206 agents with minimal side effects (21).

With global COVID-19 vaccination in its initial stages, the timeframe for full

208 global vaccination is still unknown. Several population groups, such as the youngest

209 age groups and people with health limitations, will take longer to vaccinate.

210 Therefore, a preventative antiviral treatment to be used in conjunction with vaccines

211 or even temporarily until vaccination or other alternatives become available would

212 be valuable.

213 The objective of this study was to evaluate the anti-viral activity of the NT-

214 VRL-1 terpene formulation, with and without CBD, against human HCoV-229E in

215 human lung fibroblasts in vitro. In this study, we report the antiviral activity of the

216 NT-VRL-1 terpene formulation and show that that activity was enhanced when it was

217 applied together with $\mathrm{CBD}$, suggesting either a synergetic or additive effect between

218 the terpene formulation and CBD. Several studies have suggested that

219 phytochemicals found in cannabis may be useful as potential anti-inflammatory

220 agents $(22,23)$. Such activity may be particularly useful for controlling the cytokine

221 storm syndrome and acute respiratory distress syndrome associated with COVID-19.

222 This study is the first to test cannabis phytochemicals for use against a coronavirus. 
224 effective against SARS-associated coronaviruses (17), was used as positive control.

225 Glycyrrhizin, which has been shown to have antiviral effect against SARS-associated

226 coronaviruses (24), served as the second positive control.

227 The mode of antiviral action of NT-VRL-1 was determined by the addition of

228 the compounds to uninfected lung cells, before or after those cells were inoculated

229 with HCoV-229E. The time-of-addition assays can help us to determine the point(s)

230 at which our compound inhibits HCoV-229E replication.

231 Our results demonstrate that NT-VRL-1's antiviral effect was most

232 pronounced in the pretreatment system, which may indicate that the compounds'

233 antiviral effect is based on the prevention of viral attachment and/or entry. Under

234 these conditions, both CBD (at $0.5-1 \mu \mathrm{g} / \mathrm{mL}$ ) and NT-VRL-1 (at 2-10 $\mu \mathrm{g} / \mathrm{mL}$ ) exhibited

235 observable antiviral effects, as did the positive controls (pyrazofurin at $5 \mu \mathrm{g} / \mathrm{mL}$ and

236 glycyrrhizin at $400 \mu \mathrm{g} / \mathrm{mL})$. In addition, when CBD $(1 \mu \mathrm{g} / \mathrm{mL})$ and NT-VRL-1 (10

$237 \mu \mathrm{g} / \mathrm{mL}$ ) were applied together, we observed a synergistic antiviral effect that was

238 even stronger than that observed for the positive controls.

239 Terpenes have been shown to have antiviral activity against SARS-CoV (17,

240 19). However, in previous studies, the terpenes were added to the virus at the same

241 time and no time-of-addition assays were performed. To the best of our knowledge,

242 this is the first report on the antiviral mode of action of terpenes and CBD against a

243 coronavirus.

244 NT-VRL-1 exhibited an antiviral effect and should preferably be pre-incubated

245 with cells prior to virus exposure. The combination of NT-VRL-1 with CBD amplified

246 this antiviral effect. These results suggest that NT-VRL with or without CBD could be 
useful as a preventative measure against coronaviruses. As the lungs are the organs

248 most affected by COVID-19, preventative treatment directly to the lungs, possibly via

249 inhalation, would be the ideal administration route for this potential therapeutic

250 solution.

252 Acknowledgments: We thank Eybna team for their constant encouragement

253 throughout this project. We would like to thank Ina Stelmah and Shlomit Lempert

254 for their supportive efforts and helpful suggestions. We gratefully acknowledge the

255 support of our work and our ideas by our partner Seach Medical Group. Finally, we

256 thank Yaakov Amidror for the valuable discussions related to this work. 


\section{References}

258 1. Belouzard S, Millet JK, Licitra BN, Whittaker GR. 2012. Mechanisms of coronavirus cell entry mediated by the viral spike protein. Viruses 4:1011-1033.

2. Signer J, Jonsdottir HR, Albrich WC Marc Strasser, Züst R, Ryter S, Ackermannvirucidal activity of Echinaforce ${ }^{\circledR}$, an Echinacea purpurea preparation, against coronaviruses, including common cold coronavirus 229E and SARS-CoV-2. Virol J 17:136.

3. World Health Organization Coronavirus Disease (COVID-19) Dashboard (https://covid19.who.int/)

4. Ma Q, Li R, Pan W, Huang W, Liu B, Xie Y, Wang Z, Li C, Jiang H, Huang J, Shi Y, Dai J, Zheng K, Li X, Hui M, Fu L, Yang Z. 2020. Phillyrin (KD-1) exerts anti-viral and anti-inflammatory activities against novel coronavirus (SARS-CoV-2) and human coronavirus 229E (HCoV-229E) by suppressing the nuclear factor kappa B (NF-KB) signaling pathway. Phytomedicine 78:153296.

5. Parang K, El-Sayed NS, Kazeminy AJ, Tiwari RK. 2020. Comparative antiviral activity of remdesivir and anti-HIV nucleoside analogs against human coronavirus 229E (HCoV-229E). Molecules 25(10):2343.

6. Pene F, Merlat A, Vabret A, Rozenberg F, Buzyn A, Dreyfus F, Cariou A, Freymuth F, Lebon P. 2003. Coronavirus 229E-related pneumonia in immunocompromised patients. Clin Infect Dis 37(7):929-932. Gay CG. 2018. Phytochemicals as antibiotic alternatives to promote growth and enhance host health. Vet Res 49(1):76. 
8. McGarvey DJ, Croteau R. 1995. Terpenoid metabolism. Plant Cell 7:1015-1026.

9. Prakash V. 2017. Terpenoids as source of anti-inflammatory compounds. Asian J Pharm Clin Res 10:68-76.

10. Guimarães AG, Quintans JS, Quintans LJ. 2013. Monoterpenes with analgesic activity--a systematic review. Phytother Res 27(1):1-15. M, Scherer R. 2019. Antibacterial activity of terpenes and terpenoids present in essential oils. Molecules 24(13):2471.

12. Astani A, Reichling J, Schnitzler P. 2010. Comparative study on the antiviral activity of selected monoterpenes derived from essential oils. Phytother Res.

13. Astani A, Schnitzler P. 2014. Antiviral activity of monoterpenes beta-pinene and limonene against herpes simplex virus in vitro. Iran J Microbiol 6(3):149-155.

14. Yang Z, Wu N, Zu Y, Fu Y. 2011. Comparative anti-infectious bronchitis virus (IBV) activity of (-)-pinene: effect on nucleocapsid (N) protein. Molecules

15. Zamora A, Edmonds JH, Reynolds MJ, Khromykh AA, Ralph SJ. 2016. The in vitro and in vivo antiviral properties of combined monoterpene alcohols against segetum and Oenanthe crocata. Planta Med 75(12):1331-1335. 
17. Cinatl J, Morgenstern B, Bauer G, Chandra P, Rabenau H, Doerr HW. 2003. Glycyrrhizin, an active component of liquorice roots, and replication of SARSassociated coronavirus. Lancet 361(9374):2045-2046.

18. Haiying L, Na H, Xiaoyuan X. 2003. The curative effects of glycyrrhizin on patients with SARS. Annual Meeting of the Society of Infectious and Parasitic Diseases, Chinese Medical Association, Wuhan, China, Oct. 18-22.

19. Loizzo MR, Saab AM, Tundis R, Statti GA, Menichini F, Lampronti I, Gambari R, Cinatl J, Doerr HW. 2008. Phytochemical analysis and in vitro antiviral activities of the essential oils of seven Lebanon species. Chem Biodivers $5(3): 461-470$.

20. Tyrrell DA, Bynoe ML. Cultivation of viruses from a high proportion of patients with colds. Lancet. 1966 1(7428):76-7.

21. Biswas D, Nandy S, Mukherjee A, Pandey DK, Dey A. 2020. Moringa oleifera Lam and derived phytochemicals as promising antiviral agents: a review. S Afr J Bot 129:272-282.

22. Kovalchuk A, Wang B, Li D, Rodriguez-Juarez R, Ilnytskyy S, Kovalchuk I, Kovalchuk O. 2021. Fighting the storm: could novel anti-TNF $\alpha$ and anti-IL-6 C. sativa cultivars tame cytokine storm in COVID-19? Aging 13, advance online publication. https://doi.org/10.18632/aging.202500.

23. Anil SM, Shalev N, Vinayaka AC, Nadarajan S, Namdar D, Belausov E, Shoval I, Mani KA, Mechrez G, Koltai H. 2021. Cannabis compounds exhibit antiinflammatory activity in vitro in COVID-19-related inflammation in lung epithelial cells and pro-inflammatory activity in macrophages. Sci Rep 11:1462. 
bioRxiv preprint doi: https://doi.org/10.1101/2021.03 01.433501. this version posted March 2 2021. The copyright holder for this preprint (which was not certified by peer review) is the author/funder, who has granted bioRxiv a license to display the preprint in perpetuity. It is made available under aCC-BY 4.0 International license.

327 24. Hoever G, Baltina L, Michaelis M, Kondratenko R, Baltina L, Tolstikov GA, Doerr

328 HW, Cinatl J. 2005. Antiviral activity of glycyrrhizic acid derivatives against

329

SARS coronavirus. J Med Chem 48(4):1256-1259.

330

331 


\section{Figure Legends}

333 Figure 1: Cytotoxicity test. MRC-5 cells were treated with different concentrations of

334 the compounds for $72 \mathrm{~h}$. Cell viability was then determined using an XTT assay.

335 Results represent mean percent viability $\pm \operatorname{SEM}(n=4)$.

Figure 2: Protective effect of pretreatment of MRC-5 cells with the compounds against HCoV-229E infection. MRC-5 cells were first pretreated with different concentrations of the compounds for $1 \mathrm{~h}$ and then exposed to HCoV-229E for an

340 additional $72 \mathrm{~h}$. Cell viability was determined using an XTT assay. Results represent

341 mean percent viability \pm SEM $(n=4)$. Statistics are presented for each treatment 342 compared to cells treated with HCoV-229E only. ${ }^{*} p<0.05,{ }^{*} p<0.01$ and ${ }^{* * *} p<$ 3430.001 , according to a $t$-test.

345 Figure 3: Effects of pretreatment of MRC-5 cells with terpenes and CBD on the 346 replication and cytopathic effect of HCoV-229E. (A) Healthy MRC-5 cells, (B) MRC-5 347 cells that had been pretreated with assay medium, photographed $72 \mathrm{~h}$ after 348 inoculation with HCoV-229E, (C) MRC-5 cells that had been pretreated with 349 terpenes, photographed $72 \mathrm{~h}$ after infection with HCoV-229E, (D) MRC-5 cells that 350 had been pretreated with terpenes and CBD, photographed at $72 \mathrm{~h}$ after infection 351 with HCoV-229E.

353 Figure 4: Effect of pretreatment of HCoV-229E with the compounds on the viability 354 of MRC-5 cells. HCoV-229E was treated with different concentrations of the compounds for $1 \mathrm{~h}$ and then incubated with MRC-5 cells for an additional $72 \mathrm{~h}$. Cell 
viability was determined using an XTT assay. Results represent mean percent viability

358 with HCoV-229E that had not been pretreated. ${ }^{*} p<0.05$ and ${ }^{* * *} p<0.001$,

359 according to a $t$-test.

360

361 Figure 5: Effect of pretreatment of HCoV-229E with terpenes and CBD on its

362 replication and cytopathic effect in MRC-5 cells. (A) Healthy MRC-5 cells, (B) MRC-5

363 cells at $72 \mathrm{~h}$ after infection with HCoV-229E that had been pretreated with assay

364 medium, (C) MRC-5 cells at $72 \mathrm{~h}$ after infection with HCoV-229E that had been

365 pretreated with terpenes and(D) MRC-5 cells at $72 \mathrm{~h}$ after infection with HCoV-229E

366 that had been pretreated with terpenes and CBD.

368 Figure 6: Protective effects of compounds on MRC-5 cells after virus adsorption.

$369 \mathrm{HCoV}-229 \mathrm{E}$ was first added to MRC-5 cells for $1 \mathrm{~h}$. Then, different concentrations of

370 compounds were added to the cells for an additional $72 \mathrm{~h}$. Cell viability was

371 determined using an XTT assay. Results represent mean percent viability \pm SEM $(n=$

372 4). Statistics are presented for each treatment relative to cells treated only with

373 HCoV-229E. ${ }^{*} p<0.05$ and $* * * p<0.001$, according to a $t$-test.

375 Figure 7: Effects of terpenes and CBD applied post-infection on the replication and

376 cytopathic effect of HCoV-229E in MRC-5 cells. (A) Healthy MRC-5 cells, (B) MRC-5

377 cells at $72 \mathrm{~h}$ after infection with $\mathrm{HCoV}-229 \mathrm{E}$, (C) MRC-5 cells that were pretreated

378 with terpenes, photographed $72 \mathrm{~h}$ after infection with HCoV-229E and (D) MRC-5 
bioRxiv preprint doi: https:/doi.org/10.1101/2021.03.01.433501· this version posted March 2, 2021. The copyright holder for this preprint

(which was not certified by peer review) is the author/funder, who has granted bioRxiv a license to display the preprint in perpetuity. It is made available under aCC-BY 4.0 International license.

379 cells that were pretreated with terpenes and CBD, photographed $72 \mathrm{~h}$ after infection

380 with HCoV-229E.

381

382 
bioRxiv preprint doi: https://doi.org/10.1101/2021.03.01.433501· this version posted March 2, 2021. The copyright holder for this preprint (which was not certified by peer review) is the author/funder, who has granted bioRxiv a license to display the preprint in perpetuity. It is made available under aCC-BY 4.0 International license.

Figure 1:

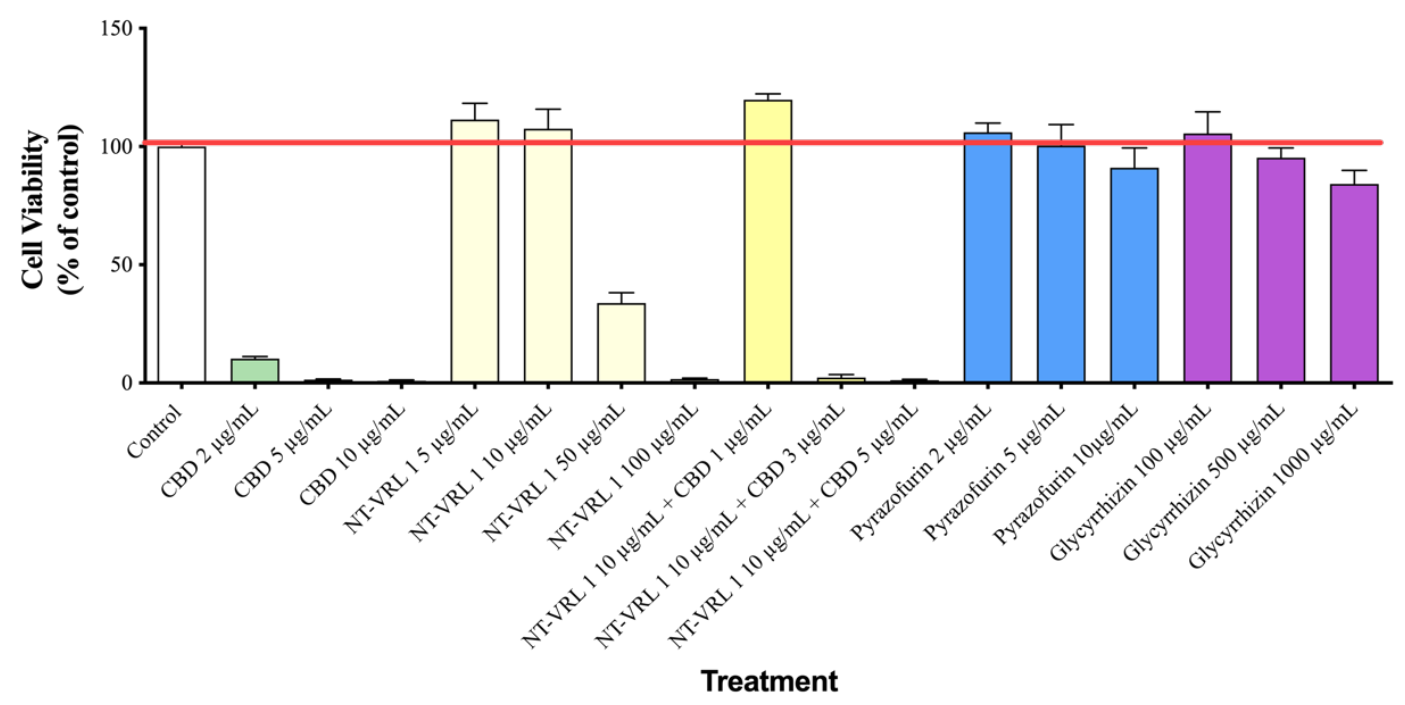

385 Cytotoxicity test. MRC-5 cells were treated with different concentrations of the

386 compounds for $72 \mathrm{~h}$. Cell viability was then determined using an XTT assay. Results

387 represent mean percent viability $\pm \operatorname{SEM}(n=4)$. 


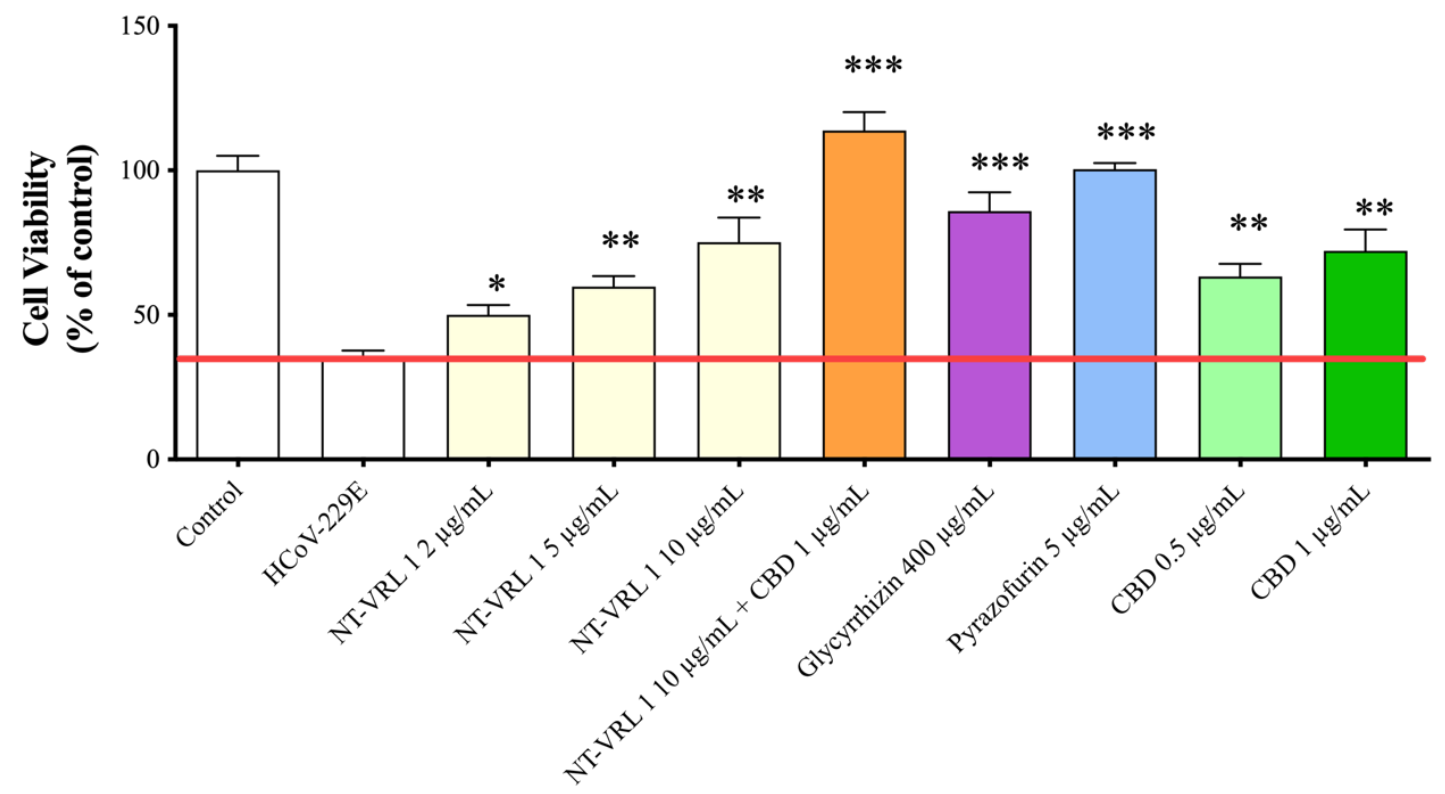

Treatment

392 229E infection. MRC-5 cells were first pretreated with different concentrations of the

393 compounds for $1 \mathrm{~h}$ and then exposed to HCoV-229E for an additional $72 \mathrm{~h}$. Cell

394 viability was determined using an XTT assay. Results represent mean percent viability

$395 \pm \operatorname{SEM}(n=4)$. Statistics are presented for each treatment compared to cells treated

396 with HCoV-229E only. ${ }^{*} p<0.05, * * p<0.01$ and ${ }^{* * *} p<0.001$, according to a $t$-test. 
bioRxiv preprint doi: https://doi.org/10.1101/2021.03 01.433501. this version posted March 2 2021. The copyright holder for this preprint (which was not certified by peer review) is the author/funder, who has granted bioRxiv a license to display the preprint in perpetuity. It is made available under aCC-BY 4.0 International license.

400
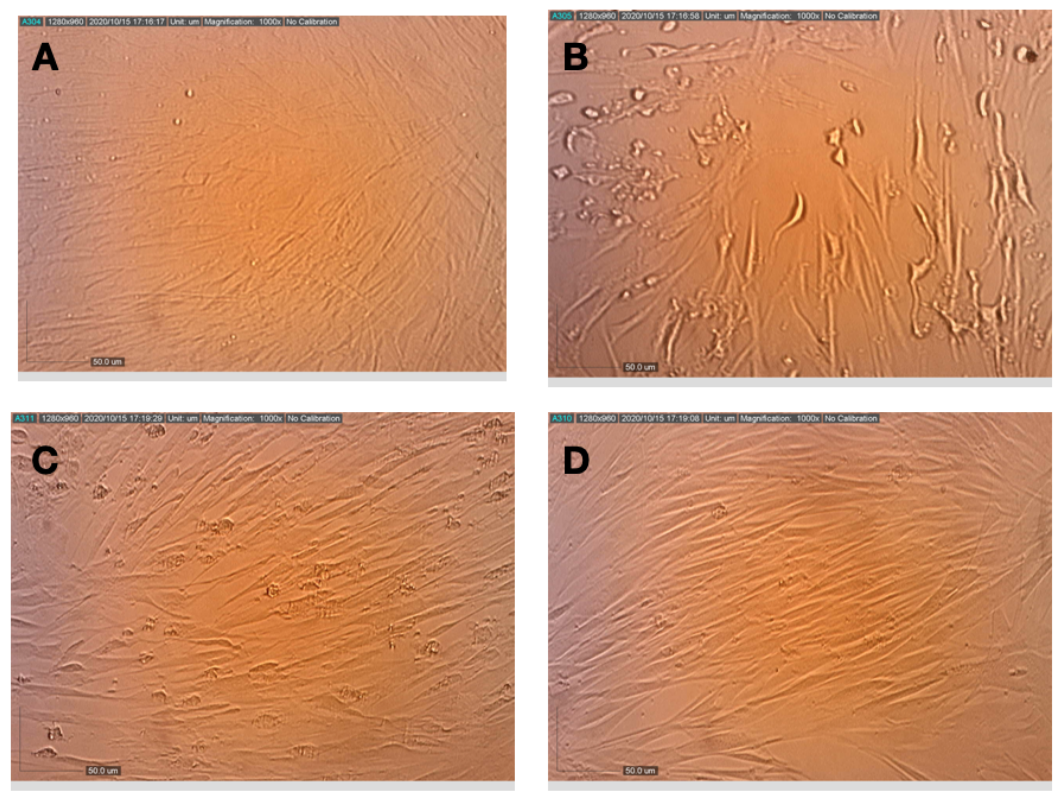

402 Effects of pretreatment of MRC-5 cells with terpenes and CBD on the replication and

403 cytopathic effect of HCoV-229E. (A) Healthy MRC-5 cells, (B) MRC-5 cells that had

404 been pretreated with assay medium, photographed $72 \mathrm{~h}$ after inoculation with

$405 \mathrm{HCoV}-229 \mathrm{E},(\mathrm{C}) \mathrm{MRC}-5$ cells that had been pretreated with terpenes, photographed

$40672 \mathrm{~h}$ after infection with HCoV-229E, (D) MRC-5 cells that had been pretreated with

407 terpenes and CBD, photographed at $72 \mathrm{~h}$ after infection with $\mathrm{HCoV}-229 \mathrm{E}$.

408

409

410 


\section{$411 \quad$ Figure 4:}

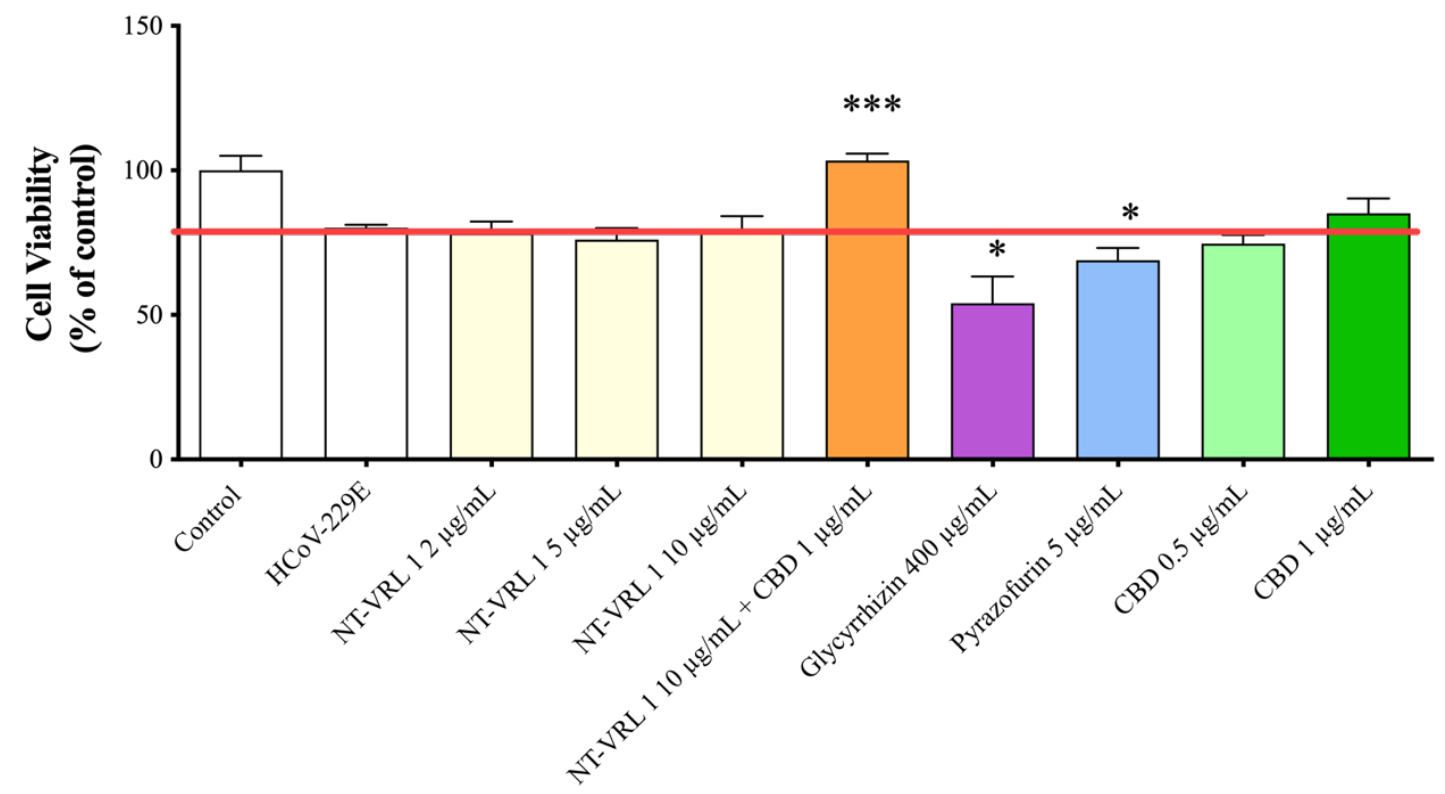

Treatment

413 Effect of pretreatment of HCoV-229E with the compounds on the viability of MRC-5

414 cells. HCoV-229E was treated with different concentrations of the compounds for $1 \mathrm{~h}$

415 and then incubated with MRC-5 cells for an additional $72 \mathrm{~h}$. Cell viability was

416 determined using an XTT assay. Results represent mean percent viability \pm SEM $(n=$

417 4). Statistics are presented for each treatment relative to cells treated with HCoV-

418229 E that had not been pretreated. ${ }^{*} p<0.05$ and ${ }^{* * *} p<0.001$, according to a $t$-test. 
bioRxiv preprint doi: https://doi.org/10.1101/2021.03.01.433501; this version posted March 2, 2021. The copyright holder for this preprint (which was not certified by peer review) is the author/funder, who has granted bioRxiv a license to display the preprint in perpetuity. It is made available under aCC-BY 4.0 International license.

\section{Figure 5:}

427
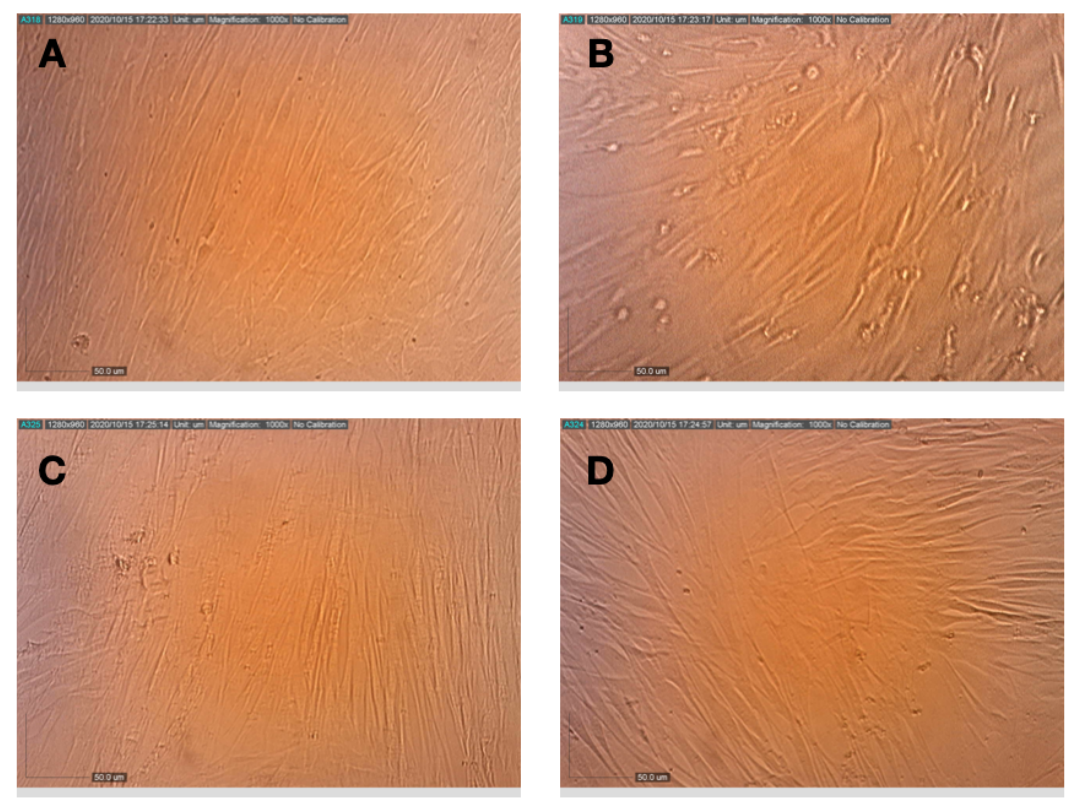

429 Effect of pretreatment of HCoV-229E with terpenes and CBD on its replication and

430 cytopathic effect in MRC-5 cells. (A) Healthy MRC- 5 cells, (B) MRC-5 cells at $72 \mathrm{~h}$ after

431 infection with HCoV-229E that had been pretreated with assay medium, (C) MRC-5

432 cells at $72 \mathrm{~h}$ after infection with $\mathrm{HCoV}-229 \mathrm{E}$ that had been pretreated with terpenes

433 and(D) MRC-5 cells at $72 \mathrm{~h}$ after infection with HCoV-229E that had been pretreated

434 with terpenes and CBD. 


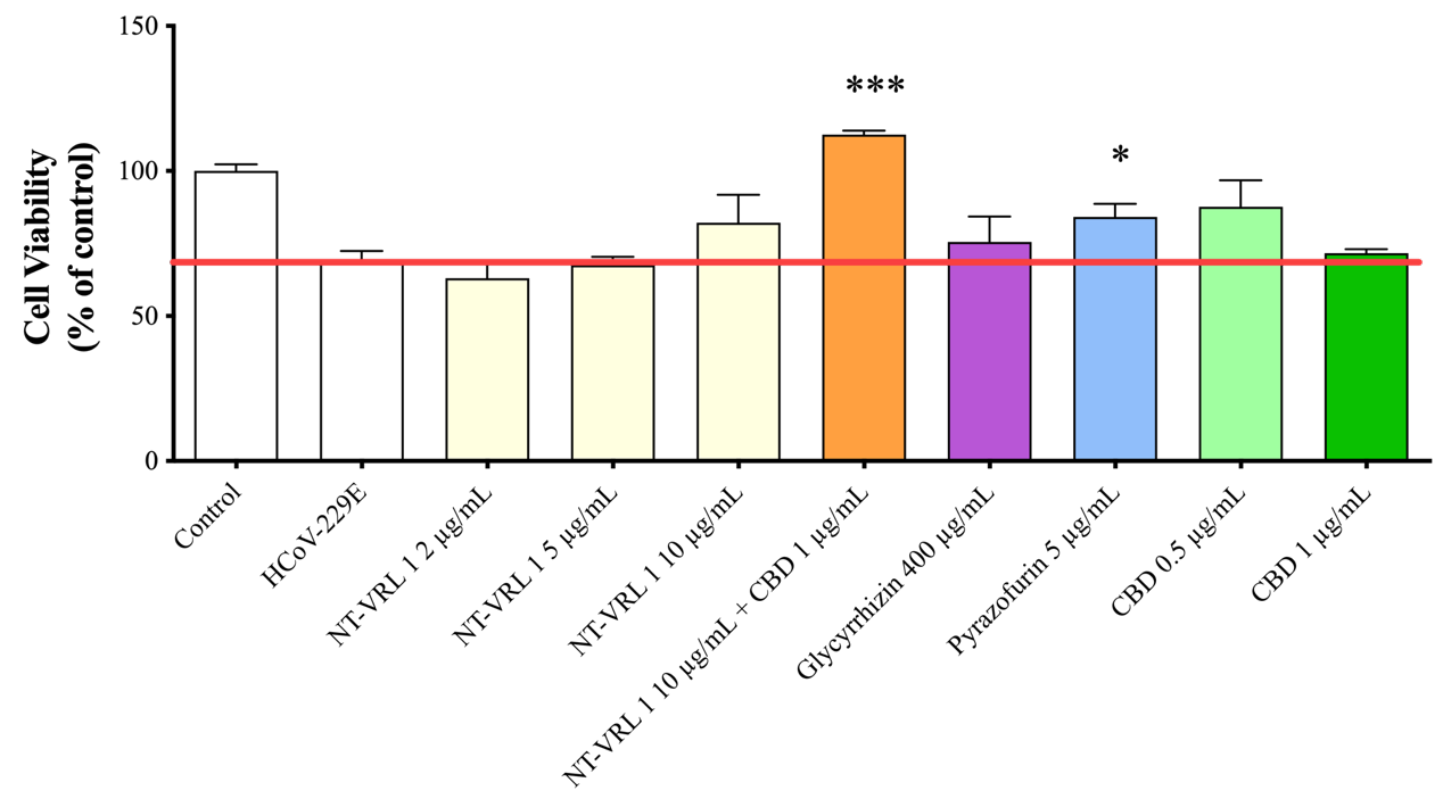

439 Protective effects of compounds on MRC-5 cells after virus adsorption. HCoV-229E

441 were added to the cells for an additional $72 \mathrm{~h}$. Cell viability was determined using an

442 XTT assay. Results represent mean percent viability \pm SEM $(n=4)$. Statistics are

443 presented for each treatment relative to cells treated only with $\mathrm{HCoV}-229 \mathrm{E} .{ }^{*} p<$

4440.05 and $* * * p<0.001$, according to a $t$-test. 
bioRxiv preprint doi: https://doi.org/10.1101/2021.03.01.433501; this version posted March 2, 2021. The copyright holder for this preprint (which was not certified by peer review) is the author/funder, who has granted bioRxiv a license to display the preprint in perpetuity. It is made available under aCC-BY 4.0 International license.

\section{Figure 7:}

453
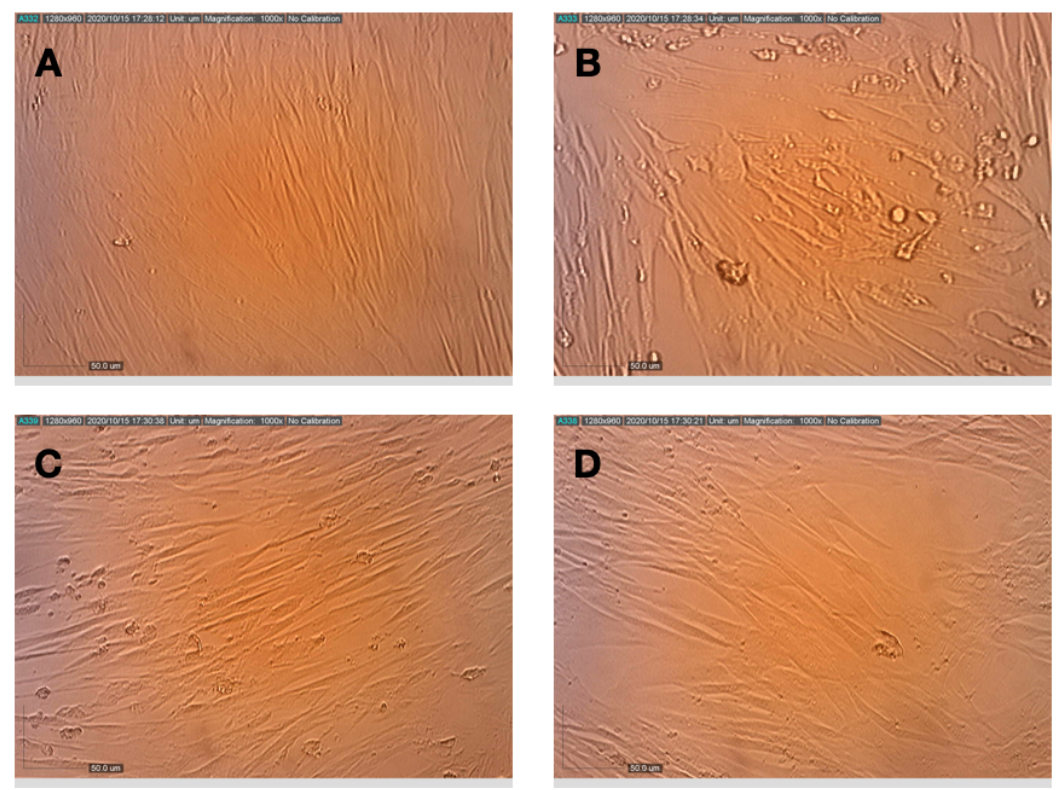

454

455 Effects of terpenes and CBD applied post-infection on the replication and cytopathic

456 effect of HCoV-229E in MRC-5 cells. (A) Healthy MRC-5 cells, (B) MRC-5 cells at $72 \mathrm{~h}$

457 after infection with HCoV-229E, (C) MRC-5 cells that were pretreated with terpenes,

458 photographed $72 \mathrm{~h}$ after infection with HCoV-229E and (D) MRC-5 cells that were

459 pretreated with terpenes and CBD, photographed $72 \mathrm{~h}$ after infection with HCoV-

$460 \quad 229 \mathrm{E}$.

461 